\title{
Commercial Arbitration Agreements and the Uniform Commercial Code
}

\author{
Dale Beck Furnish $\dagger$
}

In recent years, arbitration has become very important to the resolution of commercial disputes in the United States. In 1957, the American Arbitration Association (AAA) reported 645 commercial arbitrations. By 1967 , there were 1,588. In 1977, commercial arbitrations under the auspices of the AAA numbered 4,550. ${ }^{1}$ Untold num-

$\dagger$ Professor of Law, Arizona State University. B.A. 1962, Grinnell College; J.D. 1965, University of lowa; LL.M. 1970, University of Michigan.

My thanks to Associate Dean James J. White of Michigan, the best articles editor at the Michigan Law Review, who read this article in an early draft and may recognize some of his suggestions used and some rejected.

1. Letter from Eastman Arbitration Library (May 8, 1978). Since 1957, the annual number of cases handled by the AAA's Commercial Tribunal has been:

$\begin{array}{lr}1957 & 645 \\ 1958 & 710 \\ 1959 & 674 \\ 1960 & 783 \\ 1961 & 800 \\ 1962 & 887 \\ 1963 & 985 \\ 1964 & 1,186 \\ 1965 & 1,276 \\ 1966 & 1,449 \\ 1967 & 1,588 \\ 1968 & 1,634 \\ 1969 & 1,964 \\ 1970 & 2,658 \\ 1971 & 2,672 \\ 1972 & 3,087 \\ 1973 & 3,228 \\ 1974 & 3,809 \\ 1975 & 4,128 \\ 1976 & 4,093 \\ 1977 & 4,550\end{array}$

Solne indication of the magnitude of these numbers inay be gained through a comparison with the number of commercial opinions reported in the U.C.C. Reporter Service. The Service is notably complete and prints many opinions not included in the general reporters. From 1970 to the first month of 1978 , there were 4,477 commercial cases reported by the U.C.C. Reporter Service, in its volumes 6-22. These were predominantly appellate opinions. During the same period the AAA Commercial Tribunal took 28,225 arbitrations. Only a fruit inerchant can compare apples and oranges, and I attempt no categorical conclusion here as to the relative frequency of arbitration compared to litigation in commercial controversy. I feel safe, however, in concluding that there is a great deal of arbitration and its incidence is growing faster than the number of commercial 
bers were held outside AAA offices. ${ }^{2}$ For reasons detailed immediately below, the increasingly rapid growth in the use of commercial arbitration is almost certain to continue. Despite the trend toward judicial acceptance of arbitration, ${ }^{3}$ some courts misapply section 2-207 of the Uniform Commercial Code to nullify arbitration provisions in many commercial controversies. It is the thesis of this Article that many of the barriers to greater use of arbitration that courts draw from the Uniform Commercial Code are the result of misguided analysis. This Article suggests that the Code be amended to assure that courts interpret section 2-207 consistently with federal law governing arbitration in order to facilitate the continued growth of arbitration as a forum for resolving commercial disputes.

Several developnents in commercial usage and judicial administration as well as in the law itself have combined to spur the use of arbitration. A dramatic increase in the cost and delay inherent in litigation has led to a search for alternatives. Also, since modern commercial contracts often cannot specify all terms of an agreement, ${ }^{4}$ the parties frequently prefer to rely on arbitration to keep the transaction, which is often part of a continumg relationship, running smoothly. The Supreine Court's 1967 decision in Prima Paint Corp. v. Flood \& Conklin Manufacturing Co., ${ }^{5}$ which established the separability of arbitration clauses and thus insulated them from general attack on their "container" contracts, has made it more difficult to challenge the validity of such clauses in contracts governed by the United States Arbitration Act.

It is beyond question that the crowded calendars of our court systems have led to a new appreciation of arbitration. Arbitration has

appeals. I have canvassed several potential sources of arbitration statistics and data on commercial litigation and am convinced that no one has inore than the skimpy data set out here.

2. After pursuing hard statistics on such arbitrations over several months and through many agencies, I am convinced that no one knows how many arbitrations may occur outside AAA offices. The AAA is unique and unquestionably predominates. It is not unlikely that even when the original arbitration agreement does not designate the AAA, the parties will turn to the Association.

International transactions frequently designate the International Chamber of Commerce or local commercial institutes. The Stockholm Chamber of Commerce was designated to arbitrate all controversies growing out of U.S. - U.S.S.R. trade and a routine clause to that effect is included in trade contracts between the two countries. See 3 Y.B. CoM. ARB. 299 (D. Sanders ed. 1978).

3. See, e.g., Board of Educ. v. W. Harley Miller, Inc., 236 S.E.2d 439 (W. Va. 1977); Grover-Dimond Assoc. v. American Arbitration Ass'n, 297 Minn. 324, 211 N.W.2d 787 (1973).

4. See, e.g., Syinposium, Arbitration Clauses-Valuable Methods for Solving Business Problems Arising in Long-Term Business Arrangements, 28 Bus. LAw. 585 (1973).

5. 388 U.S. 395 (1967). The decision went relatively unnoticed in the hiterature. Only two lead articles dealt with it. Aksen, Prima Paint v. Flood \& Conklin-What Does It Mean?, 43 ST. John's L. Rev. 1 (1968); Coulson, Prima Paint: An Arbitration Milestone, 23 Bus. LAw. 241 (1967). Only three law journals published student notes on the case: 43 N.Y.U.L. Rev. 565 (1968); 46 TeX. L. Rev. 260 (1967); 42 WASh. L. Rev. 621 (1967). 
played a significant role in dispute resolution for some time and has delivered practical awards with speed, economy, privacy, and procedural flexibility - all qualities notably lacking in the judicial process. These facts have not been lost on those who have sought to relieve the courts of their currently staggering burden. Both in proposed ${ }^{6}$ and enacted ${ }^{7}$ legislation, arbitration has figured prominently among the solutions to the dilemina.

Merchants, particularly those in certaim trades, have known about arbitration for many years. They long ago ceased using carefully negotiated contracts tailored to each specific deal. Today, merchants are likely to fire off boilerplate forms as routime procedure with hittle reliance on the welter of self-serving provisions drafted into them. In the event of a controversy, it is not uncominon for countervailing boilerplate terms to cancel one another out. In such cases, a valid arbitration clause may save the game for parties who can go before arbitrators familiar witl their industry and empowered to resolve the dispute within their fiexible discretion. By contrast, judicial proceedings would seek parties' intent where they had none, or at least impose costly restrictions on procedure, evidence, and remedies.

It is not only in absence of a negotiated contract that arbitration is useful. Parties to long-term contracts often may specify little more than a relationship and an intent to do business with each other. They leave essential terms such as price, quantity, even items of exchange and inuch more to be worked out at intervals by the parties alone andwhenever the parties fail to reach an expeditious understanding-by an arbitrator. The motive for such contracts sometimes comes from the need to contract in anticipation of commercial, financial, industrial, scientific, and technological developments not in existence at the time the agreement was made. However, a simple preference for reliance on arbitration instead of attempting to wrestle complexities into the four corners of a contract document sometimes may be just as strong a reason. The gaps thus imposed, or calculatedly left, im such contracts mev-

6. See Proceedings, National Conference on the Causes of Popular Dissatisfaction with the Administration of Justice, 70 F.R.D. 79 (1976). See also Barton, Behind the Legal Explosion, 27 STAN. L. REv. 567 (1975).

A "Consumer Controversies Resolution" has been introduced in Congress "to create or develop mechanisms for the effective, fair, mexpensive and expeditious resolution of disputes," and includes arbitration among its prime mechanisms. H.R. 2482, S. 957, 95th Cong., 1st Sess. (1977). In his May 4, 1978 speech to the Los Angeles County Bar Association, President Carter promised to review "suggestions for reducing litigation, including more arbitration . . . and experiments with alternative systems for resolving disputes, such as the experimental arbitration systems now in existence in San Francisco, Philadelphia, and other parts of the country." 64 A.B.A.J. 840, 846 (1978).

7. See, e.g., ARIz. Rev. STAT. $\S \S 12-1501$ to -1518 (West Supp. 1978); N.Y. INS. LAw $\S 674(2)$ (McKinney 1978); PA. STAT. ANN. tit. 5, §§ 1-208 (Purdon 1978). 
itably give rise to many circumstances which at best would stall and at worst would einbitter or terminate existing relations if terms were not firmly and quickly defined to fill them. Commercial arbitration apparently avoids this problem by consistently providing early resolution and forestalling mercantile strife which inght otherwise imperil the marketplace.

I

\section{The Federal Arbitration Act and the Prima Paint DECISION}

In spite of its virtues, arbitration is a vulnerable remedy. Its use depends both on the agreenent of the parties to submit to it and, since it was barred at common law, ${ }^{8}$ on enabling legislation. Simce World War II, liberal arbitration statutes have been adopted throughout the country, although more than a dozen states do not yet have modern legislation. ${ }^{9}$ There are three principal models: the Umited States Arbitration Act, ${ }^{10}$ the Model Act now adopted by twenty states, ${ }^{11}$ and the New York Arbitration Act. ${ }^{12}$ Without exception, these statutes contemplate bimding commitment to arbitration of prospective matters, ${ }^{13}$ impose a statute-of-frauds requirement on arbitration agreements, ${ }^{14}$ and provide for court action to stay legal proceedings that contravene the agreement to arbitrate ${ }^{15}$ or to force arbitration upon a recalcitrant party. ${ }^{16}$ There are no major substantive differences in any of the three modern statutes.

The Federal Arbitration Act, which became law in 1925, probably lias had the greatest impact on the statutory trend in favor of arbitration. The Act applies to all contracts involving maritime commerce or

8. The prohibition is an anachronistic rule growing out of the seventeenth-century jurisdictional battles between English courts. See generally Sturges \& Reckson, Common Law and Staltttory Arbitration: Problems Arising from their Coexistence, 46 MinN. L. REv. 816, 831-44 (1962).

9. For a comprehensive list of state statutes, see M. DOMKE, COMmERCiAl ARbitration, app. 1 (1968 \& Cum. Supp. 1977).

10. 9 U.S.C. $\$ \S 1-14$ (1976).

11. See 7 UnIForm Laws ANN. 1. States that have adopted the Model Act include Arizona, Colorado, Illinois, Massachusetts, Michigan, Minnesota, and Texas. None had adopted the Act prior to 1959.

12. N.Y. Civ. Prac. LAw $\$ \$ 7501-7514$ (McKinney 1964). See also Cal. Civ. Proc. Code $\S \S 1280-1288.8$ (West 1972); N.J. STAT. ANN. $\$ \$ 2 A: 24-1$ to -10 (West 1952); PA. Stat. ANN. tit. 5, $\S \S 161-181$ (Purdon 1975).

13. 9 U.S.C. $\$ 2$ (1976); N.Y. Crv. Prac. LAW 7501 (McKinney 1964); Uniform ARaITRATION ACT \& 1 .

14. See note 13 supra.

15. 9 U.S.C. $\$ 3$ (1976); N.Y. Civ. Prac. LAW $\$ 7502$ (a) (McKinney 1964); UNIForM ArbITRATION ACT \& 2(d).

16. 9 U.S.C. $\$ \S 4,5$ (1976); N.Y. Crv. Prac. LAW $\$ \S 7502$ (a), 7503(a), 7504 (McKinney 1964); UNIFORM ARBITRATION ACT $\S \S 2(a), 3$. 
"evidencing a transaction involving" commerce "anong the several States or with foreign nations." 17 Its basic substantive provision is section 2 , which provides that any arbitration clause "shall be valid, irrevocable, and enforceable, save upon such grounds as exist at law or in equity for the revocation of any contract." 18 The two major enforcement provisions follow in sections 3 and 4 , which provide for a stay of proceedings "brought in any of the courts of the United States upon any issue referable to arbitration" and "an order directing that such arbitration proceed in the manner provided for in such agreement." 19 As a defensive strategy, then, any commercial party who does not wish to arbitrate customarily attacks the basic agreement. It is the only issue he can raise, for once in force arbitration subsumes all other issues.

\section{A. The Separability of Arbitration Clauses}

Given the imterstate nature of much of the commerce in the Umited States, the Act might have ratified inost arbitration clauses even in states in which the local statute did not. However, before Prima Paint, even the clearest arbitration clauses often were susceptible to legal attack by signatories who alleged fraud in the inducement of the contract, ${ }^{20}$ a lack of inutuality, ${ }^{21}$ the assertion of a frivolous claim in the arbitration, ${ }^{22}$ or an unfulfilled condition precedent to arbitration. ${ }^{23}$ So long as repudiating parties were able to lock the arbitration clause into its container-agreeinent, they could strike down the clause by successfully attacking the overall transaction. As a dilatory tactic, the mere allegation was sufficient. Thus arbitration was often frustrated "by a litigant's cry of . . . a claim that would require a preliminary court adjudication in every case where the cry was raised."24 Only if an arbitration clause were severable froin its container-agreement and subject to a separate test of validity could the advantages of arbitration be preserved against this strategy.

The question of separability caine before the Supreme Court in $1966^{25}$ in Prima Paint. The broad standard clause recommended by the

17. 9 U.S.C. $\S \S 1,2$ (1976).

18. 9 U.S.C. $\& 2$ (1976).

19. 9 U.S.C. $\S \S 3,4$ (1976).

20. See Wrap-Vertizer Corp., 3 N.Y.2d 17, 142 N.E.2d 366 (1957).

21. See Exercycle Corp. v. Maratta, 9 N.Y.2d 329, 174 N.E.2d 463 (1961).

22. See International Ass'n of Machinists v. Cutler-Hammer, 287 N.Y. 519, 74 N.W.2d 464 (1947).

23. See Board of Educ. v. Heckler Elec. Co., 7 N.Y.2d 476, 166 N.E.2d 666 (1960).

24. El Hoss Eng'r \& Transp. Co. v. American Indep. Oil Co., 289 F.2d 346, 349 (2d Cir. 1961).

25. Earlier, the issue was raised in the case of Robert Lawrence Co. v. Devonshire Fabrics, Inc., 271 F.2d 402 (2d Cir. 1959). Judge Medina upheld an arbitration clause against a claim of fraud in the inducement on the contract, pronouncing the clause subject to separate consideration. 
American Arbitration Association ${ }^{26}$ had been included in a consulting agreement executed as part of the sale of a paint business operating in several eastern states. One week after signing the agreeinent the sellerconsultant filed bankruptcy. A year later, with paynents on the consulting almost due, buyer sent a note to seller alleging breach in the inducement for fraudulent misrepresentation of solvency. Seller gave notice of intent to arbitrate his claim for payenent. Buyer responded by filing a diversity action im federal district court and simultaneously petitioning for an injuction against arbitration. Seller, in turn, invoked section 3 of the Federal Arbitration Act to stay the court proceedings pending arbitration.

The issue was squarely met, then, on classic grounds: buyer attempted to consign the controversy to court by alleging fraud in the inducement as grounds for rescinding the consulting agreement and its arbitration clause; seller countered that the issue of fraud was one for the arbitrator under the arbitration clause, the validity of which had to be tested prior to and independent of the consulting agreenent. The Court held for seller.

Prima Paint imposed the doctrine of separability, or separate and preliminary consideration of the validity of the arbitration clause: "[I]n passing upon a $\S 3$ application for a stay while the parties arbitrate, a federal court may consider only issues relating to the making and performance of the agreeinent to arbitrate." ${ }^{27}$ The doctrine places primary emphasis on the wording of the particular clause at issue and such circumstances as apply specifically to it. If the clause is as broad as the American Arbitration Association's standard clause, which is all-encompassing, ${ }^{28}$ then there would seem to be nothing which is not meet for arbitration according to the intent of the parties, judged strictly on the basis of the single clause plucked from the midst of accoinpanying exclranges and conditions.

Since arbitration clauses show up so frequently in the boilerplate of purchase orders and confirmation notices, it is not surprising that the

Id. at 409-10. The Supreme Court granted certiorari, 362 U.S. 909, then dismissed under rule 60 because the parties settled, 364 U.S. 801 (1960).

26. The American Arbitration Association suggests the following short-form arbitration clause:

Any controversy or claim arising out of or relating to this contract, or the breach thereof, shall be settled by arbitration in accordance with the Rules of [name of agency administering arbitration], and judgment upon the award rendered by the Arbitrator(s) may be entered in any Court having jurisdiction thereof.

This clause is included on the inside front cover of the arbitration rules pamphlet for various agencies or associations distributed by the AAA [hereinafter cited as AAA-recominended clause].

27. 388 U.S. at 404. See Moseley v. Electric Facilities, 374 U.S. 167, 171 (1963).

28. See AAA-recommended clause, note 26 supra. Although this model clause seems to be comprehensive, broader, more cumbersome clauses have been recominended. See Goldbero, A LawYer's Guide to Commerclal Arbitration 19-21 (1977). 
question of whether there is an agreement to arbitrate has become one of the most frequently litigated matters under UCC section 2-207.29 If one follows Prima Paint, it is the sole issue vulnerable to legal attack by a party interested in the delay or avoidance of arbitration under the United States Arbitration Act. The issue of an arbitration clause's vahidity under section 2-207 often has turned on whether it is a material alteration. Indeed, it is one of the problems favored by commentators for clarifying what constitutes a material alteration. ${ }^{30}$ It makes a fine basis for distinguishing the corroborative function of section 2-201's Statute of Frauds from the agreement to terms in section 2-207. However, it is iny arguinent here that the issue of an agreement to arbitrate should not fit under section 2-207 as it is currently constituted, despite almost everyone's long-standing presumption to the contrary. Under strict construction, article two of the UCC on sales should not apply to the issue of arbitration, since its scope does not extend beyond transactions in goods. Arbitration clauses usually appear in sales contracts or docuinents which would otherwise qualify for treatment under article two; but the separability doctrine of Prima Paint commands that the test should be an independent one ineasuring only the intent of the parties to arbitrate. ${ }^{31}$

\section{B. Prima Paint's General Intent to Arbitrate}

One might protest that if intent is the issue, then few arbitration clauses will be upheld, for parties rarely sit down and imdependently negotiate their intention to arbitrate, save in those instances in which arbitration is agreed upon after the fact of the controversy. It is essential to understand, however, that in Prima Paint the court recognized intent at a inore general level, namely, the parties' decision to pursue a standard policy of arbitration in all of their contract dealings (usually by boilerplate or arbitration clauses included on primted forms). The parties did not agree specifically to arbitrate any disagreements over seller's claim to payment for consulting or possible fraud in the induceinent to sign the contract. They simply included the most general arbitration clause possible, using the language suggested by the AAA, and

29. Annot., 72 A.L.R.3d 479 (1976).

30. See, e.g., J. White \& R. Summers, Handbook of the Law UNDer The Uniform COMMERCIAL CODE 23-33, especially 26-28 (1972); R. NORDSTROM, HANDBOOK OF THE LAW OF SALES 92-102 (1970).

31. There is no issue of a "mixed" agreement here, such as in those cases where a contract provides for a transaction in goods but transfers services as well. E.g., Bonebrake v. Cox, 499 F.2d 951 (8th Cir. 1974); See R. NoRDSTROM, supra note 30, at 44-50. Even courts utilizing a predominant-factor test should be forced to admit that the separability doctrine isolates the arbitration question from the transaction in goods. 
thereby bound themselves to arbitrate any and all issues which might arise between them.

The approach of the parties in Prima Paint was typical. Few parties carefully distinguish between those issues they agree to arbitrate and those which they prefer to litigate..$^{32}$ It is much simpler-and more likely in the heady days of initial agreement - that a broad proviso will be tossed into the exchange. The effect is to allow arbitration to proceed on all inatters of law and fact unfettered by anything in the terms of the enabling clause. This supplies substantial monentum toward arbitration. It is one thing to allow party autonomy in arbitration agreements inade after the controversy has arisen, which are quite obviously separable froin the basic (prior) agreement, and quite another to carry the separability into conteinporaneous agreements to arbitrate "any controversy or clain1 arising out of or relating to this agreement, or the breach thereof...."33

When parties include a broad arbitration clause, under the holding in Prima Paint, in effect they decide that if anything goes wrong with regard to any of the considerations and matters otherwise agreed to, then they wish to resolve the controversy through arbitration. Such intent is not part of the basic commercial agreement, but a separate matter. It treats neitler the bargain, nor its terms and performance, nor even remedies for its breach, but rather the administration of the controversies which it inay generate. In that sense the arbitration clause is distinct froin the bargain proper and not subject to the same infirmities.

The arbitration clause at issue in Prima Paint appeared in a contract signed by both parties and to that extent was a bargained term. However, there is no reason to require that arbitration be expressly bargained-for before treating it as separable from other terms. The agreeinent to arbitrate inay occur in the same way as agreement on any other term. It may be inplied where it is not expressed. ${ }^{34}$ The agreement to

32. There is of course no reason in law that they should not make such a distinction. Perlhaps the classic modern case of a valid arbitration clause which did not cover all matters was in In re Kinoshita \& Co., 287 F.2d 951 (2d Cir. 1961). The case dealt with the issue of fraud in the induceinent raised by the defendant as a basis for defeating arbitration. The arbitration clause read in part, "If any dispute or difference should arise under this Chapter." Id. at 953 . The court felt that this was restrictive enough to support arbitration only on matters involving the "interpretation of the contract and matters of performance." Id. The court went so far as to recommend the American Arbitration Association's broader standard clause and asserted that such language would have inade the question of fraudulent induceinent proper for arbitration. Id.

Kinoshita apparently is still good law, although there are not many reported cases involving valid, but limited, arbitration agreements. See J.P. Greathouse Steel Erectors, Inc. v. Blount Bros. Constr. Co., 374 F.2d 324 (D.C. Cir. 1967); American Airlines v. Louisville \& Jefferson County Air Bd., 269 F.2d 811 (6th Cir. 1959); Ocean Indus. v. Soros Assoc. Int'1, 328 F. Supp. 944 (S.D.N.Y. 1971).

33. See AAA-recommended clause, note 26 supra.

34. U.C.C. $\S \S 2-207(3), 2-204,1-205$. 
arbitrate stems from an intent which may permeate the commercial environment, subject to omission in any given transaction but often assumed by all parties to be a general policy, especially in certaim trades. $^{35}$

One should keep in mind the important differences between arbitration clauses and other terms. For example, a price ${ }^{36}$ or delivery ${ }^{37}$ term may be imposed under the UCC even though the writing offered as proof of the agreement makes no mention of price or delivery. According to arbitration statutes, every agreement to arbitrate must be backed by a written reference to arbitration, although the same statutes provide that the memorandum of the arbitration agreement need not be signed by both parties. ${ }^{38}$ In addition, since the UCC does not mention arbitration, it is not a supplemental term which can be supplied by direct reference to its own Code section. ${ }^{39}$ However, an arbitration agreement may be incorporated under the Code by reference to course of dealing, course of performance, or trade usage. ${ }^{40}$ Last, and most important, once an unlimited agreement to arbitrate is found and a sufficient writing backs it up, then arbitration, unlike any other term in a contract, triggers an exclusive process for the resolution of controversies growing out of any and all other terms in the agreement.

This Article urges that the primciples articulated in Prima Paint be given broad application. The Umited States Arbitration Act governs arbitration clauses im all contracts "evidencing" a transaction in interstate or foreign commerce (or admiralty, although that does not concern us here). Therefore, under Prima Paint, the first determination that any court, state or federal, must make in every case in which an arbitration clause is at issue, is whether there is evidence in the contract of interstate commerce. If there is, the court must proceed to consider the validity and scope of the arbitration agreement according to the standards of the United States Arbitration Act and no other. ${ }^{41}$ This preemptive effect may have awakened state courts to the benefits of

35. See, e.g., Helen Whiting, Inc. v. Trojan Textile Corp., 307 N.Y. 360, 367 (1954): "From our own experience, we can almost take judicial notice that arbitration clauses are commonly used in the textile industry ...."

36. U.C.C. $\$ \S 2-207(3), 2-305$.

37. U.C.C. $\$ \S 2-207(3), 2-307,2-308,3-309$.

38. 9 U.S.C. $\$ 2$ (1976); N.Y. CIV. PraC. LAW $\S 7501$ (1964); UNIFORM ARBITRATION ACT $\S 1$.

39. C. Itoh v. Jordan Int'l Co., 552 F.2d 1228, 1237 (7th Cir. 1977).

40. See Gaynor-Stafford Indus. v. Mafco Textured Fibers, 19 U.C.C. Rep. 740, 743-44 (N.Y. App. Div. 1976); J. WhITE \& R. Summers, supra note 30, at 27.

41. Warren Bros. Co. v. Community Bldg. Corp., 386 F. Supp. 656, 663-64 (M.D.N.C. 1974); C.P. Robinson Coustr. Co. v. National Corp. for Hous. Partnerships, 375 F. Supp. 446, 450 (M.D.N.C. 1974); Harmon Elec. Constr. Co. v. Consohdated Eng'r. Co., 347 F. Supp. 392 (D. Del. 1972). 
arbitration, for they must bless arbitration with one hand and halt it with the other whenever the state law is out of tenor with the federal act. $^{42}$

\section{Arbitration Clauses and the UCC: Current DOCTRINE}

Since its power to bind the parties to arbitrate is so encompassing, the question of what constitutes agreement on the arbiration clause assumes primary importance. Unaffected by surroundimg circuinstances and, once it is established, immune to factors which might deny the existence of the overall contract, the agreement to arbitrate is inescapably the focus of litigation to resist commercial arbitration.

The United States Arbitration Act provides that an arbitration clause shall be valid "save upon such grounds as exist at law or in equity for the revocation of any contract," and other inodern acts follow that lead. Simce article two of the UCC on sales is law im every state save Louisiana there is some mcentive to use the Code as the only cominon source of law and equity by which "any contract" might be judged. ${ }^{43}$ In addition, the agreement to arbitrate will normally arise between the same parties and in the same sorts of exchanges that are the direct concern of article two, part two, of the UCC.

Although its use as a source of law by analogy is desirable, the Code is inapposite to some aspects of arbitration agreements. A salient example is the writing requirement for an arbitration clause. The statutory requirement that any bimding arbitration clause be written may be inet by inuch less than a straightforward clause included in the mam body of a document. Courts have found that arbitration clauses may be incorporated by reference ${ }^{44}$ and may be included im purchase or-

42. Yet, as they do so, state courts cannot help but note the docket-clearing and expeditious effect of arbitration. See West Point-Pepperell, Inc. v. Multi-Line Indus., 231 Ga. 329, 332, 201 S.E.2d 452, 454 (1973); Pathman Constr. Co. v. Knox County Hosp. Ass'n., 164 Ind. App. 121, 134-39, 326 N.E.2d 844, 853-55 (1975); Pinkis v. Network Cinema Corp., 9 Wash. App. 337, 512 P.2d 751 (1973).

Of course, if a court remains blithely unaware of the application of the federal act, it will neither decide correctly nor be enlightened as to the benefits of arbitration. See Joseph L. Wilmotte \& Co. v. Rosenman Bros., 258 N.W.2d 317 (Iowa 1977).

43. See N \& D Fashions, Inc. v. DHJ Indus., Inc., 548 F.2d 722, 724 n.2 (8th Cir. 1977); Dorton v. Collins \& Aikman Corp., 453 F.2d 1161, 1163 (6th Cir. 1972). One court has turned to the UCC as the source of "federal" contract law to determine whether an arbitration clause in an international transaction was enforceable. Lea Tai Textile Co. v. Manning Fabrics, Inc., 411 F. Supp. 1404 (S.D.N.Y. 1975).

44. Bigge Crane \& Rigging Co. v. Docutel Corp., 371 F. Supp. 240 (E.D.N.Y. 1973). 
ders, ${ }^{45}$ confirmations and acknowledgements, ${ }^{46}$ and bills of lading. ${ }^{47}$ Usually, no signature or subscription is necessary to validate the writing. ${ }^{48}$ Thus the writing requirement for arbitration follows the UCC's Statute of Frauds provision, section 2-201, $\mathrm{m}$ its broad enbrace of alinost any "writing" as sufficient meinorandum of the agreement, but deviates by not insisting on a signature. This seeming paradox is not of inuch substantive importance for two reasons. First, if the written arbitration clause plucked out of the battle of the forms were subject to the exigencies of UCC section 2-207 reasoning, it would occur inost frequently in circunstances like those covered by subsections 2-201(2) and (3), which do not require signature by the receiving party. Second, and inore significant, there should be little reason to turn to section 2-201, since the writing requirements of the various arbitration statutes fulfill the function of the UCC's section.

\section{A. Arbitration Clauses as Material Alterations: The New York Saga}

In the context of litigatimg the agreement issue, there is a level on which the UCC's Statute of Frauds, section 2-201, has becoune important. The New York courts misused section 2-201(2) for a time as an analogy not for the writing requirement but for the agreement to arbitrate. Presumably the role of any writing requirement is to assure an evidentiary basis for claims in contract, a lower preliminary hurdle to the more serious matter of proving the agreement itself. Section 2201(2) provides that the lower hurdle may be cleared where, between merchants, a party receiving a confirmation has reason to know the contents of the confirmation and does not object in writing within ten days of its receipt. After this, of course, the agreement still must be proven. However, in a startling departure from the evidentiary function properly assigned to the Statute of Frauds and section 2-201(2), the New York courts converted an exception to the Statute of Frauds into a standard for assessing the existence of an agreement. These cases held that if a merchant (usually one mvolved im the textile or garment industry) who received a confirmation had reason to know that it contained an arbitration clause and did not inake written objection to it within ten days of receipt, lie was bound to arbitrate. ${ }^{49}$ To judge whether

45. Universal Oil Prod. Co. v. S.C.M. Corp., 313 F. Supp. 905 (D. Conn. 1970).

46. Gaynor Stafford Indus. v. Mafco Textured Fibers, 19 U.C.C. Rep. 740 (N.Y. App. Div. 1976).

47. Aaacon Auto Transp. Inc. v. Newman, 77 Misc. 2d 1069, 356 N.Y.S.2d 171 (N.Y. Sup. Ct. 1974).

48. See, e.g., Medical Dev. Corp. v. Industrial Molding Corp., 479 F.2d 345, 348 (10th Cir. 1973); Ocean Indus., Inc. v. Soros Assoc. Int'l, Inc., 328 F.Supp. 944,947 (S.D.N.Y. 1971). But see Tex. Rev. Civ. Stat. AnN. art. 224 (Vernon 1973).

49. The precedent-setting decision was Trafalgar Square v. Reeves Bros. Inc., 35 App. Div. 
there was "reason to know" of the arbitration clause, the courts turned to course of dealing between the parties ${ }^{50}$ and usages of the trade. ${ }^{51}$ This misuse of section 2-201(2) may have developed as an antidote to the per se classification of arbitration clauses as material alterations under section 2-207(2)(b) analysis, a classification that effectively prevented enforcement of the clause in many cases. ${ }^{52}$

Section 2-207, entitled "Additional Terms in Acceptance or Modi-

2d 194, 315 N.Y.S.2d 239 (1970). The New York cases that have followed Trafalgar Square apparently have not been reported in the official system, but were picked up by the UCC Reporting Service, which published several of the arbitration cases from the appellate division's 1975 term. Klockner, Inc. v. C. Itoh \& Co. (America) Inc., 17 U.C.C. Rep. 915 (N.Y. Sup. Ct. 1975); In re Millicent Sportswear Corp., 17 U.C.C. Rep. 914 (N.Y. Sup. Ct. 1975); Young Times, Inc. v. Charter Fabrics, Inc., 17 U.C.C. Rep. 913 (N.Y. Sup. Ct. 1975); In re C.M.I. Clothesmakers, Inc., 17 U.C.C. Rep. 911 (N.Y. Sup. Ct. 1975); In re Les Belles Enterprises, Inc., 17 U.C.C. Rep. 909 (N.Y. Sup. Ct. 1975). Whether every term produced a like number of unreported orders to arbitrate on the basis of § 2-201(2), or whether this was an exceptional shower of opinions, is nowhere indicated. Other cases in accord also are not included in the official system, but are more scattered in the service. E.g., Copen Assoc. v. Dan River, Inc., 18 U.C.C. Rep. 62 (N.Y. Sup. Ct. 1975); In re Wolfkill Feed \& Fertilizer, 16 U.C.C. Rep. 1188 (N.Y. Sup. Ct. 1975); Better Togs v. Abaco Fabrics, 8 U.C.C. Rep. 1230 (N.Y. Sup. Ct. 1971); Braten Apparel v. Rutgers Fabrics, 8 U.C.C. Rep. 345 (N.Y. Sup. Ct. 1970). In any case, one could certainly conclude that the rule was well entrenched in New York, primarily but not exclusively regarding transactions between merchants in the garment trades.

The 1966 Revision of comment 6 to $\$ 2-207$ contains language that one might invoke to support this result: "If no answer is received within a reasonable time after additional terms are proposed, it is both fair and commercially sound to assume that their inclusion has been assented to." It would be a mistake to use that language here. Only "additional terms" can be brought into the agreement under comment 6 's reference to $\$ 2-201(2)$. In effect, all the comment does is try to ensure that the acceptance or confirmation will be taken as a written memoranduin of the basic agreement including all of the standard terms that it has set out. However, under the Prima Paint doctrine, any arbitration clause must be viewed as separate from the sale of goods. As a separate agreement, it can scarcely bind the parties as a mere "additional term."

In the ultimate analysis, the test should always be essentially the same whether one is evaluating an arbitration clause as a separate agreement, a material alteration, or an additional term. Once the writings disagree or there is only a single writing, the existence of a separate agreement depends on its recognition through course of dealing, course of performance, or trade usage save in those rare cases in which the parties may have orally referred to the manner of dispute resolution. Material alterations and additional terms are the two sides of a single coin. One refutes classification as the former by showing that course of dealing, course of performance, or trade usage make a term to arbitrate one which should engender neither hardship nor unfair surpriseie., that it is a mere additional term.

50. See, e.g., Copen Assoc. v. Dan River, 18 U.C.C. Rep. 62,63 (N.Y. Sup. Ct. 1975); Braten Apparel v. Rutgers Fabrics, 8 U.C.C. Rep. 345, 346 (N.Y. Sup. Ct. 1970).

51. See In re Wolfkill Feed \& Fertilizer Corp., 16 U.C.C. Rep. 1188, 1194-95 (N.Y. Sup. Ct. 1975); Loudon Mfg., Inc. v. American \& Efird Mills, Inc., 46 App. Div. 2d 637, 638, 360 N.Y.S.2d 250,251 (1974). The use of course of dealing and trade usage is consistent with the Code's test for $\$ 2-201(2)$, but the Code makes clear that "the burden of persuading the trier of fact that a contract was in fact made orally prior to the written confirmation is unaffected." U.C.C. $\$ 2-201(2)$, comment 3.

52. Annot., 72 A.L.R.3d 479, 496 (1976). The initial precedent for New York's rule that arbitration clauses constituted material alterations was Doughboy Indus. Inc. v. Pantasote Co., 17 App. Div. 2d 2I6, 233 N.Y.S.2d 488 (1962), followed in In re Barclay Knitwear, 8 U.C.C. Rep. 44 (N.Y. Sup. Ct. 1970); Empire Steel Trading Co. v. Parson \& Crosland, 5 U.C.C. Rep. 1180 (N.Y. 
fication," is the code provision which would appear to be most applicable in judging the validity of arbitration clauses. ${ }^{53}$ Section 2-207(2) provides that between merchants additional terms become part of the contract unless "(a) the offer expressly limits acceptance to the terms of the offer; (b) they materially alter it; or (c) notification of objection to them has already been given or is given within a reasonable time after notice of them is received." Typically, parties may agree to the sale of goods by a telephone call, a telegram, or a letter in which no reference to arbitration is made. An excliange of forms, or the sending of a form by one party, typically follows. The forms are likely to include arbitration clauses. If botli parties include the same clause in their communication, the coincidence creates a clear agreement to arbitrate. On the otlier liand, if two arbitration clauses are present and there is a material discrepancy between them, then section $2-207(2)(b)^{54}$ makes it virtually impossible for them to become part of the agreement. ${ }^{55}$ In sucli event, only offeror's express assent to the clause, an unlikely occurrence in the battle of the forms, could make it binding. Section 2-201(2) provided a handy-if manifestly incorrect-means of circumventing this barrier to arbitration.

After Prima Paint, it is liard to understand why courts continued to find section 2-201(2)'s covert route to the enforcement of arbitration clauses more attractive than a straightforward disavowal of the per se material-alteration rule. The whole point of separability and its corollary, the general intent to arbitrate, is to make arbitration muclı easier to enforce. The characterization of an arbitration clause as a material alteration becomes ludicrous if the clause is separable, for it must be an alteration from something. Under Prima Paint, if a general intent to arbitrate exists by independent and preliminary measure, then the parties must arbitrate because they agreed to do so. If a general intent is

Sup. Ct. 1969); Application of Chem. Corp., 22 App. Div. 2d 865, 254 N.Y.S.2d 324 (1964). Doughboy was not a textiles contract; it involved a sale of bulk film.

53. Indeed, the arbitration clause is favored by commentators as an example of what constitutes a material alteration. See, e.g., R. NordSTROM, LAW of SALES 92-102 (1970); J. White \& R. SUMMERS, supra note 30 , at 28-33.

54. Doughboy has been followed outside New York. See, e.g., Frances Hosiery Mills, Inc., v. Burlington Indus., Inc., 285 N.C. 344, 204 S.E.2d 834 (1974); Windsor Mills, Inc. v. Collins \& Aikman Corp., 25 Cal. App. 3d 987, 101 Cal. Rptr. 347 (1972). These cases would have been more defensible before Prima Paint, when the court in Doughboy could properly state that "the agreement to arbitrate must be direct and intention made clear, without implication, inveiglement or subtlety." 17 App. Div. 2d 216, 220; 233 N.Y.S.2d 488, 492, (1962).

55. Many of the situations im which the question of arbitration arises will fall under comment 7 to $\S 2-207$. The contract is established by the acceptance of or payment for shipped goods and "it is not necessary to determine which act or document constituted the offer and which the acceptance." U.C.C. \& 2-207, Comment 7. The analysis is the same, however. If only one form includes an arbitration clause, it will not be included so long as it is a per se material alteration. See text accompanying note 111 supra. 
lacking, then arbitration is improper because the parties did not agree to it. The question of material alteration thus never comes up under proper application of the separability doctrine.

Prima Paint's separability rule should have engendered a fresh approach to arbitration clauses in New York. Instead, the state courts delayed six years before following Prima Paint and adopting the separability doctrine. ${ }^{56}$ Perhaps New York was precedent-bound by its well-developed case law of commercial arbitration. In 1975, the federal district court for the Eastern District of New York cut through the subterfuge and refused to use section 2-201(2) in the way the state courts had. The court stated, "Comphance with the Statute of Frauds is not the issue here; it is whether the arbitration provision im Petitioner's 'contract of sale' constituted an agreement to arbitrate under 9 U.S.C. $\S \S 3$ and 4." 57 The court held that an arbitration provision was a naterial alteration under contemporary New York law and denied arbitration. The next year, the Appellate Division of the New York Supreme Court changed the rule on per se materiality to one which weighs the issue on a case-by-case basis. ${ }^{58}$

Had the matter ended there or had the appellate division's rule been ratified by the New York Court of Appeals, all might have been well. An enlightened test for materiality under section 2-207(2)(b) would have allowed straightforward consideration of the parties' expectations or intent regarding arbitration. There would have been no further need for makeshift support for arbitration jerry-built on a misguided constrnction of section 2-201(2). The attitude of the court of appeals, as expressed in dicta im previous arbitration cases, appeared for a time to be receptive to such an approach. When New York adopted the separability doctrine in 1973, in Weinrott v. Carp, the court's opinion spoke of the "salutary function of arbitration agreements," $" 59$ and of an attitude toward arbitration clauses which depended "more on policy than on the wording of the provision itself." 60 The court noted evidence of "legislative intent to encourage arbitration"61 in New York's statutory provisions and also the essential similarity between the New York and Federal Arbitration Acts. ${ }^{62}$ Also mentioned by the court were the desirability of uniformity between state and fed-

56. Weinrott v. Carp, 32 N.Y.2d 190, 298 N.E.2d 42, 344 N.Y.S.2d 848 (1973).

57. John Thallon \& Co. v. M \& N Meat Co., 396 F. Supp. 1239, 1244 (E.D.N.Y. 1975).

58. Lehigh Valley Indus. v. Armtext, Inc., 53 App. Div. 2d 582, 384 N.Y.S.2d 837 (1976);

Gaynor-Stafford Indus. v. Mafco Textured Fibers, 52 App. Div. 2d 481, 384 N.Y.S.2d 788 (1976).

59. 32 N.Y.2d 190, 194, 298 N.E.2d 42, 44, 344 N.Y.S.2d 848, 852 (1973).

60. Id. at 196,298 N.E.2d at 45,344 N.Y.S.2d at 853.

61. Id. at 199,298 N.E.2d at 47,344 N.Y.S.2d at 856 .

62. Id. at 198,298 N.E.2d at 47,344 N.Y.S.2d at 856. 
eral law ${ }^{63}$ and the "worthwhile goal" of saving "the time and resources of both the courts and the parties." 64 The Weinrott opimon stated that the "main goal of the court's inquiry . . . is to discern the parties" intent"65 with regard to arbitration. New York's highest court appeared fully to have embraced the trend toward increased use of arbitration.

However, New York's highest court took an unfortunate step backward in 1978. In Marlene Industries v. Carnac Textiles, Inc., ${ }^{66}$ the court of appeals reasserted the rule that arbitration clauses are per se material alterations, relying on the 1962 appellate division case of Doughboy Industries, Inc. v. Pantasote Co. the Marlene decision is difficult to explain. In the first place, its facts seem to fit easily under section 2-207(2)(a), and thus any discussion of material alteration under subsection (2)(b) should have been precluded. The case involved a simultaneous exchange of forms following an oral agreement for the sale of fabrics. The acknowledgement-of-order form sent by the seller included an arbitration clause. The buyer's form did not mention arbitration and included an express limitation clause which provided that the purchase order could not be "superceded [sic] by an unsigned contract notwithstanding retention." $"$ "67

In Marlene, the court of appeals took the lower court to task for "applying § 2-201(2)"68 and the appellate division opimon does refer to that section. However, it is also clear that it relied on section 2-207 to uphold arbitration. ${ }^{69}$ The higher court did not note that fact, perhaps because the appellate division opinion is so painfully sketchy. The true significance of Marlene Industries is that it signals a radical reversal in the attitude of the high court toward arbitration. Changes in the court's judicial persoimel may have had something to do with the shift. Judge Breitel, who wrote the Doughboy opimon in 1962, did not participate in Weinrott. Chief Judge Fuld retired from the court of appeals after the term in which Weinrott was decided and Judge Breitel succeeded him in the chief judgeship.

Ultimately, the Marlene decision rests on a belief in the superiority of court procedures over arbitration. However, unless one is prepared to argue a special virtue in the costs, delays, and procedural miceties of judicial determination compared to the economy, speed, and flexibility of arbitration, there is no current reason for holding agreements to arbitrate to a specially elevated standard. Parties are as apt to object to

\footnotetext{
63. Id. at 199 n.2, 298 N.E.2d at 48 n.2, 344 N.Y.S.2d at 856 n.2.

64. Id. at 199,298 N.E.2d at 47,344 N.Y.S.2d at 856.

65. Id. at 197-98, 298 N.E.2d at 46,344 N.Y.S.2d at 855.

66. 24 U.C.C. Rep. 257 (1978).

67. Id. at 258 .

68. Id.

69. Marlene Indus. Corp. v. Carnac Textiles, Inc., 22 U.C.C. Rep. 888, 890 (App. Div. 1977).
} 
arbitration because they hope that the delays and costs of a court suit may give them extra leverage as they are to object because they expect a different result in a court.

Marlene is surprising not only because it bucks the current trend in the law, but also because it is a much stricter imposition of the per se material alteration rule than was the 1962 precedent on which it is based. Doughboy dealt with a trade in which arbitration was not ingrained. Marlene, to the contrary, concerned the textile trade in New York City, where arbitration may be nnore universally accepted than im any other industry in the Uinited States. ${ }^{70}$

An unwary commentator might sum up the evolution of the New York law of arbitration clauses in sales of goods as follows: although lower courts favored arbitration through misuse of section 2-201(2) for a time and it appeared New York might adopt a judicial attitude favoring arbitration under straightforward use of section 2-207(2), the court of appeals has spoken definitively against easy encouragement of arbitration through upholding clauses for its use. The Doughboy rule still applies, substantially strengthened and extended by Marlene. However, the summary is not so easily composed. If the agreement to arbitrate is viewed independently of the transaction in goods-as it should be after Prima Paint and Weinrott - then perhaps the New York courts were a bit closer to correct application of section 2-201(2). ${ }^{71}$ The recipient should be viewed as receiving two distinct confirmations im one

70. See note 35 supra.

71. There is no doubt that New York abandoned the Trafalgar Square line of cases, see note 49 and accompanying text supra, after the federal district court decision in John Thallon. There is, however, a lingering doubt in this author's unind as to exactly what it is that the New York courts abandoned. Trafalgar Square and the cases following it relied to a high degree on a prc-Code case, Matter of Helen Whiting, Inc., 307 N.Y. 360, 121 N.E.2d 367 (1954). In Helen Whiting, the court said: "From our own experience, we can almost take judicial notice that arbitration clauses are commonly used in the textile industry . . . " 307 N.Y. at 367,121 N.E.2d at 370 . If this were taken to imply an agreennent to arbitrate, still subject to a writing requirement, then perhaps the New York courts' rule was precisely that for which I am arguing: one in which customs, usage, and course of dealing or perfornance may create the basic agreement to arbitrate. See note 48 supra (final paragraph).

One can read some of the New York cases closely without being able to discern whether § 2201(2) is being used to confirm the implied basic agreement with a corroborative writing, or whether the basic agreenent is being found on the basis of the unilateral form. This is true of the Trafalgar Square case, which apparently initiated the New York rule in 1970. Trafalgar Square v. Reeves Bros., 35 App. Div. 2d 194, 315 N.Y.S.2d 239 (1970). See In re C.M.I. Clothesmakers, 17 U.C.C. Rep. 911 (N.Y. Sup. Ct. 1975). Even a 1975 case which apparently did not follow Trafalgar Square, In re Associated Lerner Shops of America, 17 U.C.C. Rep. 348 (N.Y. Sup. Ct. 1975), was careful to base its holding not on a rejection of New York's aberrational § 2-201(2)-rule, but on the grounds that "the written form of confirmation [with the arbitration clause] was received after the fabrics had been rejected" by buyer. $I d$. at 350 (emphasis in original). Not all judges in New York were so careful, however, and there were decisions that clearly held that \$ 2-201(2) was a test for the basic agreement. See, e.g., In re Millicent Sportswear, 17 U.C.C. Rep. 914 (N.Y. Sup. Ct. 1975); Young Times v. Charter Fabrics, 17 U.C.C. Rep. 913 (N.Y. Sup. Ct. 1975). 
writing: the first, a confirmation of the sale; the second, a confirmation of the agreeinent to arbitrate. It then becomes a test of his notice of the delivery of a memorandum of the arbitration agreement to determine whether the recipient knew or had reason to know that the sales confirination should contain such a clause. This construction seems truest to the separability doctrine: there would be no written agreement for arbitration where only one communication provided for it. Lacking a written agreeinent, although not the sufficient written memorandun of an agreeinent by other ineans, enforceable arbitration then becomes a question of parties' intent. The question's decision will be highly dependent upon a court's general view of arbitration. If a strict standard is imposed-e.g., no "implication, subtlety, or inveiglement"72 - then an arbitration clause will be easy to classify as a material alteration and will generally be inuch more difficult to uphold.

In fact, if not in New York, commercial arbitration is fast approaching the kind of acceptance courts had reserved for labor arbitration. United Steelworkers v. Warrior \& Gulf Navigation Co. ${ }^{73}$ one of the opinions in the Steelworkers trilogy, described labor arbitration as "the substitute for imdustrial strife," 74 and held that all doubts should be resolved in favor of its use. ${ }^{75}$ Although at that time the court drew a distinction between labor and commercial arbitration, calling the latter a "substitute for litigation," the two may have drawn together simce 1967 and Prima Paint. Many courts state a direct prejudice in favor of commercial arbitration. As the Sixth Circuit said recently, "there is a strong federal policy in favor of arbitration. This is true in the realm of commercial transactions as well as labor relations."77

72. Marlene Indus. v. Carnac Textiles, Inc., 22 U.C.C. Rep. 888, 891 (App. Div. 1977); Doughboy Indus., Inc. v. Pantasote Co., 17 App. Div. 2d 216, 223, 233 N.Y.S.2d 488, 496 (1962).

73. 363 U.S. 574 (1960).

74. Id. at 578 .

75. Id. at $582-83$.

76. Id. at 578 .

77. Georgia Power Co. v. Cimarron Coal Corp., 526 F.2d 101, 106 (6th Cir. 1975), cert. denied, 425 U.S. 952 (1976). Accord, General Guaranty Ins. Co. v. New Orleans Gen. Agency, Inc., 427 F.2d 924, 928 (5th Cir. 1970); Griffin v. Semperit of America, Inc., 414 F. Supp. 1384, 1390-91 (S.D. Tex. 1976); Grover-Dimond Assoc. v. American Arbitration Ass'n, 297 Minn. 324, 327, 211 N.W.2d 787, 788 (1973). But see Note, The Consequences of a Broad Arbitration Clause Under the Federal Arbitration Act, 52 B.U.L. REv. 572, 592 (1972), which states:

Labor policies slould not necessarily be the source of law governing commercial arbitration. There are very substantial differences between the labor and the commercial situa-

tions . . . for labor disputes resulting in strikes can cripple the entire economy. . . .

A commercial arbitration clause, unlike a labor arbitration provision, serves predominantly to implement the parties' intent. It is their understanding of the agreement that should be of foremost significance. In light of the differences, there appears to be no persuasive reason for abandoning those rules of contractual interpretation and equitable analysis whicl lave been developed to aid the courts in ascertaining the intent and the fairness of any individual contract.

Although it is right to focus on the parties' intent, this view is incorrect for the reasons cited in the 
Merchants are less bound to their goods than are laborers to their work. Commercial disputes seldom carry the violent potential of "industrial strife." However, the objectives of contractual exchange in our society-security of transaction, party autonomy, and salutary freemarket trading, according to the Restateinent Second ${ }^{78}$ - frequently are served best today by arbitration rather than hitigation. In commerce, as in labor, the contemporary complexity of bargaining creates too inany contingencies for parties to rely on their ability to define rights, duties, and terms at the time of contracting or on the costly process of litigation to resolve their subsequent disputes. The Marlene rule that arbitration clauses are material alterations is not only in direct conflict with many recent decisions, ${ }^{79}$ but is also mcreasingly out of tenor with the generally adopted approach to section 2-207. Recently, some courts have emphasized the imterrelationship between section 2-207 and section 2-204, with corresponding sensitivity to the pragmatics of the marketplace and a proclivity to find a contract where parties should have felt a commitment. ${ }^{80}$ At least im inany important industries, parties to

text: the intent of the parties with respect to the arbitration clause is prospective and general. Their contract does becoine in essence "a generalized code to govern a myriad of cases which the draftsinen cannot wholly anticipate." United Steelworkers v. Warrior \& Gulf Navigation Co., 363 U.S. at 578 (1960).

78. Restatement (Second) of Contracts \& 76, Comment b; § 81, Comment c (1973).

79. See Medical Dev. Corp. v. Industrial Molding Corp., 479 F.2d 345 (10th Cir. 1973); Dorton v. Collins \& Aikman Corp., 453 F.2d 1161 (6th Cir. 1972); Valmont Indus. v. Mitsui \& Co., 419 F. Supp. 1238 (D. Neb. 1976); American Parts. Co. v. Amcrican Arbitration Ass'n, 8 Mich. App. 156, 154 N.W.2d 5 (1967). These cases are clearly correct. The issue is far from settled, lowever. There are a substantial number of cases which follow Doughboy and would hold an arbitration clause to be a material alteration per se. Windsor Mills v. Collims \& Aikman Corp., 25 Cal. App. 3d 987, 101 Cal. Rptr. 347 (1972); Frances Hosiery Mills v. Burlington Indus., 285 N.C. 344, 204 S.E.2d 834 (1974); Just Born, Inc. v. Stem, Hall \& Co., 40 North Co. R. 183, 59 Pa. D. \& C.2d 407, (1971). See Southeastern Enameling Corp. v. General Bronze Corp., 434 F.2d 330 (5th Cir. 1970).

Despite the problematical nature of categorizing arbitration clauses for purposes of $\S 2$ 207(2)(b) under a standard of "unfair surprise or hardship," some commentators have not hesitated to make a categorical classification by calling such clauses per se material alterations. See Bernstein, The Impact of the Uniform Commercial Code Upon Arbitration, 42 N.Y.U. L. REV. 8, 17 n.25 (1967); Collins, Arbitration and the Uniform Commercial Code, 41 N.Y.U. L. REv. 736, 742-45 (1966).

The editors of the U.C.C. Reporting Service have been inaccurately accused of taking such a position. See In re Associated Lerner Shops of America, 17 U.C.C. Rep. 348, 350 (N.Y. Sup. Ct. 1975).

80. See, e.g., Ebasco Servs. v. Pennsylvania Power \& Light, 402 F. Supp. 421, 434-44 (E.D. Pa. 1975); Steiner v. Mobil Oil Corp., 20 Cal. 3d 90, 459 P.2d 751, 141 Cal. Rptr. 157 (1977); Southern Idaho Pipe \& Steel v. Cal-Cut Pipe \& Supply, 22 U.C.C. Rep. 25 (Idaho 1977); U.C.C. \$ 2-207, Comments 2, 7. In the Steiner case Justice Mosk stated:

Section 2207 is thus of a piece with other rccent developments in contract law. Instead of fastening on abstract doctrinal concepts like offer and acceptancc, $\$ 2207$ looks to the actual dealings of the parties and gives legal effect to that conduct . . . . [S]ection 2207 instructs us not to refuse to enforce contracts until we look below the surface of the parties' disagreenent as to contract terms and determine whether the parties undertook 
sales transactions will commonly expect arbitration, although their written memoranda as to their expectation will be most inconsistent. In such a situation, the agreement-by way of a standing, general intentshould be enforced so long as it is corroborated by a writmg, although no agreement on the writing per se is necessary or relevant.

\section{B. Arbitration Clauses as "Supplementary Terms": The Itoh Case}

The current unsatisfactory state of judicial analysis of arbitration clauses under the UCC is demonstrable through a leading decision by the United States Court of Appeals for the Seventh Circuit in 1977. In C. Itoh \& Co. (America) v. Jordan International Co., ${ }^{81}$ plaintiff Itoh sent defendant Jordan a purchase order for steel coils. Itoh's form made no reference to arbitration. Jordan responded with an acknowledgement form which mcluded an arbitration clause and conditioned Itoh's acceptance on assent to all of the acknowledgement's terms. Without further relevant communication, Jordan dehivered the order, for which Itoh paid. After Itoh attempted to resell the steel coils to a third party, who rejected them as defective, Itoh sued Jordan. Jordan mvoked section 3 of the United States Arbitration $\mathrm{Act}^{82}$ and requested a stay of the judicial proceeding pending arbitration.

The court found no formation of a contract to arbitrate. It properly discredited the argument that section 2-201(2) might support formation, tracing the New York precedents. ${ }^{83}$ It then properly noted that any basis for a contract to arbitrate had to be found im section 2-207 and more specifically in section 2-207(3) conduct, since Jordan's exclusive condition im the acknowledgeinent ran afoul of the specific-assent proviso at the end of section 2-207(1). ${ }^{84}$ The court found that a sales agreement existed between the parties but held that "[s]ince provision for arbitration is not a necessary or missing term which would be supplied by one of the Code's 'gap-filler' provisions unless agreed upon by the contracting parties, there is no arbitration term im the section 2207(3) contract which was created by the conduct of Jordan and Itoh." $" 85$

to close their deal. Section 2207 requires courts . . . to analyze. . . what really happens.

In this spirit, we turn to the application of $\$ 2207$ in this case.

20 Cal. 3d at 100, 569 P.2d at 758, 141 Cal. Rptr. at 164. In Ebasco the court stated that even if a clause is clraracterized as a material alteration by comment 4 to $\$ 2-207$, "final determination cannot be made without an examination of the factual circumstances surrounding the entire transaction, an examination we find inore appropriately performed by the fact finder." $402 \mathrm{~F}$. Supp. at 443 n.32.

81. 552 F.2d 1228 (7th Cir. 1977).

82. 9 U.S.C. $\$ 3$ (1976).

83. 552 F.2d at 1232-33. See Part IIA supra.

84. 552 F.2d at 1235 .

85 . Id. at 1237. 
While correct in its application of current doctrine, Itoh highlights tlie inadequacies in tliat doctrine. First, a cogent argument may be made that under section 2-207(3) an arbitration clause may be read into the contract as a fitting supplemental terin drawn from course of dealing and trade usage as authorized by UCC section 1-205(3). Second, and more properly, if the question of arbitration is severed from the sales transaction and its terms as Prima Paint dictates, it matters not whetler arbitration can be cliaracterized as a supplemental term. Rather, the conduct of the parties inust be measured against the imdependent qucstion of intent to submit to arbitration.

To begin witl Itoh's analysis of supplemental terms under section 2-207(3), the Seventh Circuit was mistaken to limit supplemental terms to those found in the "gap-filler" provisions of article two. As section 1-102(2)(b) instructs in tlie general provisions of the Code, an underlying purpose and policy of the UCC is "to permit the contimued expansion of commercial practices through custom, usage and agreement of the parties." More specifically, section 1-205 on "Course of Dealing and Usage of Trade" states: "A course of dealing between parties and any usage of trade in the vocation or trade in which they are engaged or of which they are or slrould be aware give particular meaning to and supplement or qualify terms of an agreement." ${ }^{. " 66}$ As noted before, this is proper under section 2-207(3)'s command to respect "any supplementary terms incorporated under any other provision of this Act." Awareness and consideration of such provisions, even where courts persist in viewing arbitration as inerely one of the terms im a sales agreement, sliould have led in Itoh to an inquiry into custom and trade usage in the steel industry, where arbitration is used extensively. Itolı \& Co. was acutely aware of this fact, liaving been engaged in otlier litigation over steel-coil trade arbitration in New York two years before. ${ }^{87}$

The Seventlr Circuit did not ignore totally the possibility of custom and usage creating an agreenent to arbitrate. Judge Sprecher's opmion states that "even were we to assume arguendo that . . . a disputed additional term . . . could be brought into that contract as a 'supplementary term' by imphication from custoin and usage," such a terin would be unenforceable because "federal district courts may issue a stay order only where there is an agreennent in writing for arbitration." ${ }^{88}$ This is a mistaken interpretation of the writing requirement which is every bit as egregious as the New York court's misuse of section 2-201(2). It is

86. U.C.C. \& 1-205(3) (emphasis added).

87. Klockner, Inc. v. C. Itoh \& Co. (America), 17 U.C.C. Rep. 915, 916-17 (N.Y. Sup. Ct. 1975). See Cook Indus., Inc. v. C. Itoh \& Co., 449 F.2d 106 (2d Cir. 1971) (grain trade arbitration resolved in Itoh's favor).

88. 552 F.2d at 1238 (emphasis in original). 
worse in that there are no policy grounds which might forgive the abuse. $^{89}$

The Itoh case could appear to inake the writing requirement a substantive eleinent of an arbitration agreeinent by reversing the order of proof - the factfinder determines first whether there was an agreement, then whether the writing was a full and faithful reflection of that agreeinent. Whereas the New York courts wished to prove the agreement by the existence of a written meinorandum, Itoh would demand total agreeinent on the written ineinoranduin as the only basis for an arbitration agreeinent. This approach begs the question and subverts the function of the writing. The federal provision treats an arbitration agreenent as distinctive by removing the necessity of a signature by the party against whom the writing is to be enforced. ${ }^{90}$ Thus the federal act reflects both a presuinption in favor of arbitration and the fact that an evidentiary basis for proving the existence of the agreenent would result whenever arbitration was sufficiently within the conteinplation of one of the parties that he created a written inemoranduin. The evidence would be heavily oriented towards course of dealing, course of performance, trade usage, and any specific facts dealing with the particular transaction which might be adduced to show agreenent. If such a standard could be met, it seeins indefensible that arbitration should fail because the parties - having agreed to arbitrate — did not "agree" to the written ineinorandum of their bargain.

The snarl into which Judge Sprecher and the Seventh Circuit were led in Itoh could have been avoided by applying section 2-207 to the issue of arbitration by analogy rather than literally. ${ }^{91}$ Literal application led the court to hold that an arbitration clause could never be a "supplemental term" to a sale-of-goods agreenent. This is doubtful under the section 2-207 approach detailed below, taking custorn and usage into account, but even if it were correct the separability doctrime would conflict with the Itoh conclusion that unless a duty were "supplied by the standardized 'gap-filler' provisions of article two," it should not be imposed on the parties. Proper separation of the arbitration question would lead to an independent inquiry into the parties' expectations on that single point. As indicated previously, ${ }^{92}$ courts should view a general imtent to arbitrate as pervading normal commercial intercourse im some trades and allow an agreenent to arbitrate to be found in various ways. In the same way that courts take a realistic view of agreements to sell goods and atteinpt to respect the realities of

89. Compare text at note 52 supra.

90. See note 48 supra.

91. See text accompanying notes $43-48$ supra.

92. See text accompanying notes $32-42$ supra. 
the marketplace, they should search out the realities of the marketplace regarding the use of arbitration. If courts and the lawyers who guide the courts' attention will approach the issue by focusing first on finding a basic agreement supported by the writing requireinent and then on defining its terms, inquiries into the validity of arbitration agreenents will be more realistic. Ascertaining the terms of the agreement will be substantially easier in arbitration than in a sale of goods, for the process of arbitration is largely routme and lacks the swirl of variables present in a sale. The parties trigger a process, rather than define one as in the sale.

The recent decisions on arbitration have been inconsistent. The Itoh case is a good illustration of current doctrime and its inadequacies because the Itoh court was thorough in its research, correct in some of its application of current law, and honest enough to discuss the issue with which it could not deal. Still, one worries that many courts do not yet fully coinprehend what they are doing when confronted with arbitration clauses. Most focus on UCC section 2-207 but seem uncertain precisely where they should grasp and hold an arbitration clause for its mspection and analysis. The following extended discussion of section 2-207's application to coinunercial arbitration clauses should provide guidance in approaching such probleins.

III

\section{Separate Agreements to ARbitrate Under UCC} SECTION 2-207

An analysis based on the separability of arbitration clauses under the Prima Paint decision is the correct approach to UCC section 2-207. If one views the arbitration clause as separate froin the sale-of-goods contract, which is the proper view despite its frequent inclusion, and bears in mind that the application of the UCC is only by analogy, then the requisites for finding a binding agreement to arbitrate soften appreciably. Courts should approach arbitration clauses as if they are considering a distinct contract under section 2-207. Courts then should be disposed to find an agreeinent to arbitrate in appropriate cases-that is, where parties routinely anticipate them and custoinarily respect themin the saine way they are disposed to find a contract for the sale of goods in most cases of routine coinunercial exchange.

The UCC cannot supply supplemental terms for all poimts on whiclı arbitration clauses may disagree, of course, for it is unconcerned with arbitration. However, a primciple nay be drawn from section 2207 of the UCC for use by analogy in the context of arbitration: courts should uphold any terms additional to the basic agreement to arbitrate 
so long as they do not run afoul of section 2-207(2)-style restrictions. Such a principle for arbitration could work in the following way. An offer to arbitrate might expressly limit acceptance to the terms of the offer, including arbitration in New York. When an acknowledgement included arbitration but indicated Los Angles as the site, the latter tern would be precluded under section 2-207(2)(a). In the same situation, where the offer had not insisted on its terms, the offeror might object to Los Angeles as the arbitration site within a reasonable time after receipt of the acknowledgment, thus foreclosing that term under section 2-207(2)(c). Were both parties in New York and all the operative facts connected with New York, even absent an express-assent clause the offeree's Los Angeles arbitration site term probably should be disqualified as a material alteration under section 2-207(2)(b).

It is important to fix firmly in one's, mind that the basic agreeinent to arbitrate is not an adjunct to the sales agreeinent, but the point of departure for independent analysis. Arbitration is isolated as the essential question and its terms may be estabhished by custorn and usage where the arbitration agreenent fails to supply thein. This approach assures a strong preference for arbitration, since "additional" or "supplemental" terins seldom will be an issue. Once the agreement is estabhshed, arbitration easily can follow the procedures and inechanisins established by statute. ${ }^{93}$ An approach which views the arbitration clause as part of a larger package and thus vulnerable because it is not essential to the sale-of-goods agreeinent, is retrograde both in its failure to coinprehend the impact of Prima Paint ${ }^{94}$ and its unresponsiveness to the pressures favoring liberalized arbitration as a form of rehef for crowded court dockets.

Having isolated the arbitration agreement as an independent concern, how does one go about applying section 2-207 by analogy? In many cases, both buyers' and sellers' forms routinely mclude the American Arbitration Association's broad recominended clause and the coincidence creates a clear agreement to arbitrate. ${ }^{95}$ When there is a discrepancy im the forms, however, section 2-207 is activated to resolve inconsistencies in accordance with the underlying cominercial realities.

93. See, e.g., the United States Arbitration Act, which provides for the naming of arbitrators by the court when the parties do not provide for doing so, 9 U.S.C. $\S 5$ (1976); the procedures of arbitration, $i d . \S \S 3,4,7$; and the entry of the award as a judgment, id. $\$ 9$.

94. See text accoinpanying notes $32-42$ supra.

95. Such an occurrence also creates little possibility for litigation on the grounds of no agreement to arbitrate. Reported cases deinonstrating the point, therefore, are scarce. An example of simultaneous use of the standard clause of the North American Export Grain Association is I.S. Josepl Co. v. Toufic Aris \& Fils, 54 App. Div. 2d 665, 388 N.Y.S.2d I (1976). 


\section{A. Countervailing Arbitration Clauses}

Numerous circumstances may mvoke section 2-207 and its three tests for contract: basic agreement, ${ }^{96}$ mclusion of additional terms, ${ }^{97}$ and conduct of the parties. ${ }^{98}$ A common situation occurs when both forms in the exchange imclude terms which insist on their provisions and conditions as the exclusive basis for the agreement, and the forms differ with regard to arbitration. In such a case, offsetting rejections by operation of section 2-207(2)(a) and section 2-207(1) mandate application of section 2-207(3), relying on conduct of the parties as the only possible route to contract. The sort of conduct which creates a sales contractshipinent of goods, payment, use or transformation of the goods-has little bearing on the question of agreement to arbitrate. ${ }^{99}$ This demonstrates the impropriety of inaking arbitration an mcident of the sales contract.

Since the UCC has no provisions that deal specifically with arbitration, one's first reaction might be that the UCC can be of no help im resolving the issue of whether parties have agreed to arbitrate. ${ }^{100}$ However, it seems proper that under some circumstances conduct of the parties should establish such a duty. This would be especially true of a course of dealing where arbitration liad been used by the parties several times before one of the parties subsequently objected to it, or where the trade usage was clearly to arbitrate. There is such ample support for this approach im the spirit of the UCC that one wonders why the courts have not yet considered it. The probable reason is that judicial attention has been riveted on section 2-207(3), even though an independent, severable agreement to arbitrate should not depend on being one of "those terms on which the writings of the parties agree," since a discrepancy in the writimgs regarding arbitration is the source of the controversy. Instead, one should go to the basic definition of agreeinent in section 1-201(3), which specifically includes the "bargam of the parties in fact as found . . . by imphication from . . . circumstances including course of dealing or usage of trade." This basis could be buttressed by analogy to section 2-204's standard that a contract "may be made in any manner sufficient to show agreement, including con-

96. U.C.C. $\$ 2-207(1)$.

97. U.C.C. $\& 2-207(2)$.

98. U.C.C. \& 2-207(3).

99. It is of course necessary that there be a sales agreement between the parties, else the arbitration question cannot arise. Therefore, in a sense, the conduct indicated nay be preliminary to arbitration. See In re Associated Lerner Shops of America, Inc., 17 U.C.C. Rep. 348 (N.Y. Sup. Ct. 1975).

100. See R. Duesenberg \& L. King, Sales and Bulk Transfers Under the Uniform Commercial Code \$ 3.06[4], at 73-74 (1966); J. White \& R. Summers, supra note 30, at 29; Collins, supra note 79 , at $744-45$. 
duct by both parties which recognizes the existence of such a contract." 101 For example, if one of the parties prepared to arbitrate as usual (either in transactions with the other party to the particular circumstances in controversy or with regard to transactions of that general type whenever controversies with various parties developed) and then resisted arbitration on the grounds of lack of agreement, his prior conduct proved in court might stand as recognition of the agreement to arbitrate.

The impropriety of prevailing interpretations of section 2-207(3) is more vividly illustrated by the situation in which both writimgs contained arbitration clauses, although they differed in certain particulars. For example, one writing might exempt controversies over quality from arbitration. If section 2-207(3) is turned to blindly, the minor discrepancy-in what is a clear agreement to arbitrate all controversies save those over quahty-might be invoked to find no enforceable intent to arbitrate controversies over price, delivery terms, or any other matter. The faulty reasoning would be that the parties disagreed on the matter of arbitration, and that no supplemental term is forthcoming from the UCC to provide it, since it is nowhere nrentioned specifically in the Code. ${ }^{102}$

This result and reasoning illustrate the mistake in viewing arbitration as inerely another term in the sales agreement. However, even with this misguided approach, course of dealing and trade usage might provide for arbitration as a supplementary term. Section 2-207(3) refers to "any suppleinentary terms incorporated under any other provisions of this Act," and section 1-205(3) states that course of dealing and usage of trade of which the parties "are or should be aware give partic-

101. The use of $\$ 2-204$ in conjunction with $\S 2-207(3)$ is fully endorsed by comment 7 to the latter. See J. White \& R. SUMMERS, supra note 30, at 29-30.

102. U.C.C. \$ 2-207, Comment 6. See Southwest Eng'r. Co. v. Martin Tractor Co., 205 Kan. 684, 473 P.2d 18 (1970). In that well-known case, it was quite clear that both parties had agreed that credit should be extended on a sale, but had disagreed as to its terms. Faced with the disagreement, the court turned to $\S 2-310$ (a) and made payment due at the time and place of receipt. It would have been better to have adopted a mini-2-207 approach and to have found agreement on some form of credit, since the parties were agreed as to that much. I am indebted to Professor Marion Benfield for this insight.

The mini-\$ 2-207 concept might also be described as a full contractual analysis of a given term within a specific contract. That is, once a determination is made that conduct of the parties recognizes the existence of a eertain term, such as arbitration, then the parameters of that single term could be established by what may have been accepted $(\S 2-207(1)$ ); what may have been added by written confirmation ( $\$ 2-207(2)$ ); and what may have been recognized by parties' conduct or incorporated under other provisions of the UCC, including § 1-205 (§ 2-207(3)). In the example given in the text above, both parties agreed to arbitrate, but the confirmation attempted to exempt controversies over quality from arbitration. One should then find an agreenent to arbitrate under a $\S 2-207(1)$ approach, hold the quality exemption up to a $\$ 2-207(2)$ analysis, and if it is found to represent a material alteration or a term excluded by the original author to arbitrate, then ultimately decide whether the exemption is created by a $\$ 2-207(3)$ process. 
ular meaning to and supplement or qualify terms of an agreement." Thus, even applying section 2-207 directly and viewing the arbitration clause as a part of the sales agreement, one ought to find a supplementary arbitration term where that mechanism prevailed either between the parties or im their trade. Properly, however, arbitration should be found on the basis of fundamental imdependent agreement rather than as a mere term in a sales contract.

\section{B. Offeror's Clause}

A second common set of circumstances to be resolved under another subsection of section 2-207 occurs when one party's document carries an arbitration clause but that sent by the other side does not. If the arbitration clause appears im the offeror's form and the offeree's form does not expressly make acceptance conditional on assent to a clause barring arbitration but simply ignores the matter, and the offeree proceeds to participate in a sales transaction, under conventional application of section 2-207(1) there is an arbitration clause binding on the parties. ${ }^{103}$

Agam, the impropriety of the result is apparent. An arbitration clause could be introduced via fine print in the offeror's form where arbitration could not reasonably have been anticipated by refcrence to either course of dealing or trade usage. This very powerful term would thus be mcluded by section 2-207(1) as part of the sales agreement, although the offeree may have responded to the offer with no immediate thought of arbitration. The better view, im accord with the separability doctrime, is to handle the arbitration clause imdependently and see whether there is any basis in conduct, course of dealing, or trade usage for implyming an enforceable intent to arbitrate. Where none exists arbitration should not be available, even though the Statute of Frauds would have been satisfied by the offeror's clause. Where the arbitration itself is proper, unreasonable arbitration terms such as a provision for an unanticipated, mconvenient site should not be enforced, since they fall outside the partics' legitimate expectations and intent. ${ }^{104}$

\section{Offeree's Clause}

If the arbitration clause appears only in the offcree's form (usually the confirmation or acknowledgment), then one turns to section 2-

103. J. WhITE \& R. SUMMERS, supra note 30 , at 28.

104. At least one court has adopted a forum non conveniens analysis to achieve an apparcntly similar result. Aaacon Auto Transp., Inc. v. Feldman, 77 Misc. 2d 120, 353 N.Y.S.2d 851 (N.Y. Sup. Ct. 1974). But see Sam Reisfield \& Son Import Co. v. S.A. Eteno, 530 F.2d 679 (5th Cir. 1976) (arbitration clause designation of Coutrai, Belgium as site is proper). 
207(2) in most instances. If the offeree expressly conditions his acceptance on assent to all terms and none is forthcoming from the offeror, then there is no contract to arbitrate until or unless performance creates one under section 2-207(3). ${ }^{105}$ The test should be the same as that under contervailing clauses: have the parties habitually used arbitration or is it broadly used in their trade?

Often, the arbitration clause and additional or different sales terms will not condition the acceptance. Between merchants, then, the arbitration clause will become part of the parties' agreement unless it would materially alter it. As noted, there is authority for the view that all arbitration clauses are by nature material alterations and thus cannot be incorporated into the contract. ${ }^{106}$ However, there should be no such thing as a per se material alteration. Thoughtful courts shy away from an absolute rule and look behind the concept of materiality to judge each arbitration clause by the facts of the case. Utilizing the standard of "surprise or hardship" endorsed by the official comments, ${ }^{107}$ courts have heard evidence of whether the parties have established a course of dealing including arbitration or whether arbitration is so commonly a part of commercial transactions in the particular trade or commodity that the parties commonly would have expected it or at least contemplated it sufficiently to negate any element of unreasonable surprise regardless of express awareness. ${ }^{108}$

The same result is reached whether one is careful to separate the arbitration clause from the sale-of-goods contract and use section 2-207 along with other sections by analogy or whether one simply proceeds directly under the code section and its materiality test. Under either approach, the essential question regarding the arbitration clause is wliether the parties expect and imtend it to be there. The proof of "surprise or hardship" will be virtually identical to course of dealing or trade usage, and there should be no divergence in results.

Such consistency is not present under the situations previously described, however, because section 2-207 may effectively read the arbitration clause out of ${ }^{109}$ (or into) ${ }^{110}$ the contract without taking account of the parties' intent ${ }^{111}$ (or surprise). ${ }^{112}$ Jarring results and illogical var-

105. I do, of course, reject the decision in Roto-Lith, Ltd. v. F.P. Bartlett \& Co., 297 F.2d 497 (1st Cir. 1962). It appears that one of the few matters under \$ 2-207 upon which virtual unanimity exists is that Roto-Lith was wrong. See R. DuEsenberG \& L. KING, supra note 100, at $\$ \$ 2.04$, 3.02; J. White \& R. SUMMERS, supra note 30, at 29-30.

106. See also note 79 supra.

107. U.C.C. \$ 2-207, Comments 4, 5.

108. See note 79 supra.

109. See text at note 102 supra.

110. See text at note 103 supra.

111. See text at note 102 supra.

112. See text at note 104 supra. 
iations may be avoided by treating the agreement to arbitrate as uniformly subject to the parties' expectations and intent, usually measured by course of dealing and trade usage. For the sake of umformity, then, the present Uniform Commercial Code should not apply directly to any of the situations involving the exchange of writings. It is helpful, of course, when applied by analogy in a process which carefully seeks a relevant policy in several apphicable sections without being hidebound to section 2-207. At a minimum, any construction by analogy should take into account sections 1-201(3), 1-205, 2-201, 2-204, and 2-207.

\section{Single Document with Arbitration Clause}

A corollary situation is that in which parties orally concluded an agreement without reference to arbitration, and only one sent a written confirmation. Whether there is an arbitration clause in the form or not, the temptation to apply section 2-201(2) as a substantive test might arise again. An agreement could be found in the single form between the parties because the party who received it had reason to know its contents and made no written notice of objection, especially when goods had been shipped and/or paid for. Section 2-206 inight be invoked here. ${ }^{113}$ One might argue that the noncorresponding party apparently was satisfied with the simgle written meinorandum's terms and accepted them by going ahead with the transaction. This, of course, is not a tenable approach. The question is still whether surprise or hardship was imposed by the arbitration clause as an independent offer originating either with the offeror or the offeree of the sales transaction. If the clause was present and expected, then it should bind the parties to arbitrate. This result follows whether one clings to apphication by analogy to the policy of sections 2-207(2)(b), 2-201(2), 1-205, and 2-204, or turns to custom and usage im an independent inquiry into the presence of an agreement to arbitrate, using the form clause only to satisfy the writing requirement.

If a proper course were followed, the contract should be easy to prove after section 2-201(2) reasoning has removed the Statute of Frauds as a defense for the receiving party who sent no written memorandum. The issue of arbitration is then uncomplicated and direct, and the predisposition favors its use. Although courts have found the arbitration clause of a single form to be vahid, section 2-201(2) alone cannot

113. See Universal Oil Prod. Co. v. S.C.M. Corp., 313 F. Supp. 905 (D. Conn. 1970). Duesenberg has criticized this case as turning on "a rationale exactly of the kind designed to be buried by § 2-207." Duesenberg, General Provisions, Sales, Bulk Transfers and Documents of Tille, 27 Bus. LAw 1169, 1173 (1971). It is no doubt true that Universal Oil Products is not a precedent to be held up as a shining example. I would offer the cautionary note, however, that it is in kecping with viewing the arbitration clause as separate from the sales agreement. It should be forgotten for all other purposes. 
serve as the basis for the contract. Its only function is with regard to the Statute of Frauds. The contract to arbitrate can and should be proved, if at all, under sections 2-204 and 1-205 reasoning, either by using the course of dealing and trade usages to establish conduct accepting arbitration, or by using the same standards to demonstrate that there is a justified expectation that the clause will be respected should a controversy arise.

There are limits to the proof of arbitration agreements by course of dealing and trade usages. If the simgle written form in an exchange did not include an arbitration clause, then no enforceable arbitration agreement could be found because the writing requirement could not be satisfied. If the arbitration clause were by nature only a part of the sales agreeinent, then conduct could be offered to show the existence of an agreement to arbitrate as a supplemental term supported by a written memorandum of the sale even though the writings did not mention arbitration. But this is clearly improper. Where arbitration is properly treated as an independent question, it needs independent satisfaction of its own writing requirement.

\section{E. UCC Section 2-207(3) and Comment 7}

The preceding analysis has turned on finding an offer and an acceptance in the communications between the parties. In many battles of the forms, order and confirmation will have crisscrossed, been received and filed without reading, and the goods will have been shipped, accepted, and paid for before the dispute arises. In such instances, comment 7 to section $2-207^{114}$ mdicates that it is not necessary-it would be impossible in most cases- to distinguish between the docuinents as to which is the offer and which is the acceptance.

The crossing of order and confirmation forms is a most common occurrence. For example, inost of the cases arising out of the New York textile trade fall into the category estabhshed by comment 7 . Where the contract is created by conduct, it is impossible to give one party's form the advantage of being the offer. In the same way, no express-assent clause inay foreclose the possibility of arbitration. Only those terms "on which the writings of the parties agree" will be incorporated into the bargain.

The proper analysis of the issue of arbitration where forms have crisscrossed is to turn to section 1-205 (unless both forms contain the saine arbitration clause) and determine whether course of dealing, course of performance, or trade usage create an agreement to arbitrate

114. Added to the Code in 1966 to prevent recurrence of the Roto-Lith mistake. See note 105 supra. 
between the parties. Where the parties' writings agreed that there should be arbitration but differed as to particulars such as site or whether the issue of quality was subject to arbitration, the same approach may be augmented by use of the apphicable arbitration statute as a source of supplemental terms. Of course, in either case at least one of the documents must mention arbitration lest there be failure to comply with the Statute of Frauds under the separability doctrime.

\section{CONCLUSION}

\section{UCC SECTION 2-207 SHOULd Be AMENDED}

This paper should have impressed the reader with the fact that arbitration is of critical importance to the settlement of commercial disputes in the United States today and that to a degree it has supplanted the courts in this area. Much of the current acceptance enjoyed by arbitration is new. It has developed only within the last ten years, since the Prima Paint decision began to open judicial attitudes to the virtues of arbitration. So long as the hitigation crush contimues in the courts and the complexity of commercial relationships continues to mount, arbitration will be in good odor with courts, lawyers, and commercial parties. The time when commentators expressed warning doubts about the propriety of so flexible a process, although not so long ago in time, ${ }^{115}$ is far reinoved from most current law and praetice. Reading the cases, one detects an emerging desire to refer appropriate controversies to the arbitrator, although there is also a pervading sense that courts are not so comfortable with commercial arbitration as they might be.

The status of arbitration in United States commercial law has changed radically im recent years but the law has not yet assimilated the change. Perhaps experts in the Uniform Commercial Code are not arbitrators and do not read decisions like Prima Paint. Perhaps arbitrators do not spend their time analyzing the Umiform Commercial Code. I hope that this article has helped to bridge this gap. Arbitration of commercial disputes under agreement between merchants could be accommodated by the Code applications and techniques detailed here. Reahistically, however, it is doubtful that current shortcomings under UCC section 2-207 can be overcome without a change in the Code. The Code language would support it, but the existing precedent and commentary will not. Amendments to the UCC are necessary.

There are three major concerns which should be served by additions to section 2-207. Foremost is to cast the principle of separability

115. E.g., Kronstein, Arbitration is Power, 38 N.Y.U.L. REv. 661 (1963); Jalet, Judicial Review of Arbitration: The Judicial Attitude, 45 CORNelL L.Q. 519 (1960). 
as established by the Prima Paint decision into the language of the statute. The objective should be to assure that the agreement to arbitrate is considered as an independent compact not bound to the transaction in goods. The arbitration question should be removed from the battle-ofthe-forms sales question and fought on its own separate grounds. The arbitration agreement should be made amenable to autonomous creation through the same means recognized for the creation of a sales agreement: formal written agreement, battle of the forms, conduct, or course of dealing and usage of trade. All may be served by an amendinent to section 2-207 because courts and commentators have an ingrained habit of dealing with arbitration clauses under that section of the Code.

Adjunct to the separability issue is the concern for eliminating unreasonable arbitration terms while preserving the basic agreement to arbitrate-that is, the use of a primciple drawn from section 2-207 and exclusively limited to arbitration. A final concern is that it should be possible in appropriate circumstances to create a binding arbitration agreeinent between inerchants where the only written meinorandum of the agreement is a clause in the offeree's confirmation form.

I do not inean to suggest that arbitration should always be used wherever the shightest opportunity presents itself. While it may be entrenched in certain trades or markets, it is just as likely that arbitration may be generally avoided in others. The issue is to be resolved on the facts of each case, subject to the preemptive express intent of the parties. The standards that I have detailed in this Article can be uniformly introduced through an additional code provision. If adopted, proposed section 2-207(4), set forth in full in the appendix, would substantially aid the resolution of commercial controversies by better serving the intent of the parties to arbitrate. 


\section{APPENDIX \\ Proposed UCC Section 2-207(4)}

Whenever and to the extent that course of performance, course of dealing, usage of trade, or any other independent circumstances deinonstrate an agreement to resolve commercial controversies by arbitration, such agreeınent shall be valid and enforceable between merchants notwithstanding the other provisions of this section.

\section{Official Comment}

This provision is added to section 2-207 to codify the separability doctrine of arbitration clauses established in Prima Paint Corp. v. Flood \& Conklin Manufacturing Co., 388 U.S. 395 (1967). It recognizes that for many markets and for many merchants arbitration has becoine sufficiently customary that it should be enforced independently of the tests used to measure other terms under this section. Arbitration clauses are not to be regarded as standard terms in a sales agreement between merchants. Arbitration clauses should be regarded as having nothing to do with terms dealing with quality, quantity, credit, delivery, disclaimers, or other matters which typically make up the substance of an order or confirmation form.

Arbitration is dependent for its enforceinent on no other terms. When merchants' forıns substantially agree that arbitration should occur in event of controversy, arbitration invariably should be enforced. Discrepancies in arbitration clauses are to be resolved by the use of a principle drawn froin section 2-207 and applied separately to arbitration terms. For example, an offer to arbitrate imght expressly limit acceptance to the terms of the offer, including arbitration in New York. If the acceptance indicates that arbitration is to occur in Los Angeles, the latter tern would be precluded under section 2207(2)(a). In the same situation, where the offer had not insisted on its terms, the offeror might object to Los Angeles as the arbitration site within a reasonable time after receipt of the acknowledgment, thus foreclosing that term under section 2-207(2)(c). Were both parties in New York and all the operative facts connected with New York, then the offeree's Los Angeles arbitration site terin probably should be disqualified as a material alteration under section 2-207(2)(b).

Continuing this approach, where forns crisscross and neither can be designated as either the offer or the acceptance, a contract to arbitrate must be created through conduct of the parties under a section 2-207(3) approach. If the writings of the parties agree on arbitration, of course, that is binding and subsection (3) is not used no matter what other discrepancies exist between the writings. Where the writings disagree on arbitration, conduct of the parties may be sought in their course of dealing or course of performance. For example, if the parties customarily have arbitrated previous disputes despite contractual disclaimers, then there is probably an intention to arbitrate regardless of the writing. However, trade usage is a more problematical source of contract-creating conduct. Trade usage alone probably should not create sufficient 
conduct where one of the parties expressly disavows an intent to arbitrate in its writing and has never deviated from that express intent, regardless of how deeply ingrained arbitration inay be in the parties' trade generally.

An arbitration agreement that is established under this section must meet any applicable writing requirements before it is enforceable. Because it is separable froin the rest of the agreement and its terms, no general sales agreement should be used to corroborate an arbitration agreeinent-no inatter how strongly arbitration is ingrained in the usage of the particular trade or course of dealing or performance-unless the sales agreenent specifically mentions arbitration. However, the writing requirement may be satisfied where only the confirmation mentions arbitration, under the saine sort of circumstances contemplated by section 2-201(2).

It is the belief of the drafters that the saine result that is inandated by subsection (4) of this section might be achieved by analogy and the proper apphication of sections 2-204, 1-205(3), and 1-201(3) in conjunction with sections 2-207 and 2-201. 